Special Issue on

Public Enterprise Performance Benchmarking

Public Enterprise

Volume 22, Issue 1, pp. 118-139, 2016

https://doi.org/10.21571/pehyj.2016.2201.07

\title{
Technical Efficiency Analytics for the Public Banks in Argentina
}

\author{
Vincent Charles* \\ CENTRUM Católica Graduate Business School \\ Pontificia Universidad Católica del Perú, Lima, Peru \\ Claudia Peretto \\ Facultad de Ciencias Económicas \\ Universidad Nacional de Córdoba, Córdoba, Argentina \\ Tatiana Gherman \\ School of Business and Economics \\ Loughborough University, Leicestershire, United Kingdom
}

Received July 2015; Revised December 2015; Accepted March 2016

\begin{abstract}
In a context in which the competitive landscape of the Argentinian banking industry continues to mature as a result of phenomena such as globalization, modification of regulations, new technologies, and mergers and acquisitions, the quest for higher revenues has never been more stringent. It becomes relevant, therefore, to perform systematic benchmarking through the measurement of the efficiency of the banks. The present research paper uses data envelopment analysis (DEA) to rank the Argentinian public banks based on their performance over 17 years, between 1998 and 2014. The results reveal that 1999 and 2002 were "black years" for the public banking sector, years during which the country registered political and economic and financial crises, respectively. Furthermore, the trend analysis shows that the Argentinian public banks are converging towards better consistency in their performance over the years. It is hoped that the present paper will provide the concerned authorities a ground to assess the health of the individual public banks.
\end{abstract}

Keywords: Argentinian banks, public banks, data envelopment analysis, progressive time-weighted mean

Reference to this paper should be made as follows: Charles, V., Peretto, C., and Gherman, T. (2016). Technical Efficiency Analytics for the Public Banks in Argentina. Public Enterprise, 22(1), 118-139. DOI: 10.21571/pehyj. 2016.2201.07 


\section{Introduction}

After having experienced challenging economic and financial difficulties in the 1980s, which made the banking system to practically collapse, the 1990s brought structural reforms in Argentina, including financial system reforms, liberalization of trade and the capital account, and public sector reforms (Pou, 2000). In particular, the Convertibility Law of 1991 and the Central Bank Charter of 1992 have played a fundamental role in re-shaping the financial system, by means of eliminating the inflation and proclaiming the central bank's independence of the executive and legislative branches. The liberalization process has, furthermore, opened the local market to foreign banks, increasing the competition pressure, while imposing more regulatory and market discipline. It is also interesting to note that the mergers and acquisitions, as well as the closures following the Tequila crisis in 1995 led to the number of banks to decline from 167 (of which 35 were public and 132 were private) to 119 (of which 16 were public and 103 were private) between 1991 and 1999. Additionally, during the same time period, 16 small government-owned banks were privatized (Pou, 2000). Further details on a number of features of the Argentinian banking sector will be provided in the following section.

Although progress has been made in time to establish the basis for a healthy financial system in Argentina, there are a number of ongoing concerns. According to the 2015 Index of Economic Freedom (The Heritage Foundation, 2015), Argentina occupies the $169^{\text {th }}$ place in the world rank, ranking $27^{\text {th }}$ out of 29 countries in South and Central America/ Caribbean region, with its overall score remaining far below the regional and world averages. Furthermore, according to the same source, monetary stability is particularly weak, with government interference and price controls on almost all goods and services, making Argentina's country risk premium to remain high and variable. In this context, another problem is represented by the expansion of the informal economic activities, which further distort price levels, and consequently, the financial sector.

Judging by international standards, the financial sector is still small, nevertheless, it is expected to continue growing, fact that requires the concerned authorities to consider financial innovation on their working agenda as a means to strengthen the regulatory framework. The stability of the financial system is a priority. Moreover, "small and medium-sized companies are the main sources of employment and output, and more needs to be done to improve their access to the system's financial resources without impairing loan portfolio quality” (Pou, 2000).

In brief, several sectors of the Argentinian economy have experienced profound changes in the structural conditions in which they compete, due to the pressure of phenomena such as globalization, modification of regulations, and new technologies, among others. The current economic situation faces significant challenges to achieve growth and a better integration into the world arena. The competitive conditions under which businesses are conducted today have expanded the management and comptroller function to include a future strategic direction, with the need to make large and small decisions efficiently and effectively.

Although the international literature reports a large number of studies that have been carried out to measure the efficiency and productivity of the banking sector, the great majority has been conducted in developed countries, with little or no focus on emerging economies. For example, Barros, Managi, and Matousek (2012) studied the Japanese banks, Berger, Leusner, and Mingo (1997) the American banks, Paradi, Zhu, and Edelstein (2012) the Canadian banks, and Tsolas and Charles (2015) the Greek banks, just to name a few. As such, studies in this regard for the Argentinian banking sector are rather scant and lack a more systematic research approach.

In this context, the present research work seeks to contribute to the efficiency literature with evidence from Argentina, a still relatively little explored country with a banking system that has undergone major transformations. As Mishkin and Eakins (2014) advocated, the banking sector plays a vital role in the transfer of funds, which is 
important in ensuring that both the financial systems and the economy run efficiently. Thus, the efficiency analysis can provide the concerned authorities and regulators a ground to assess the health of individual banks by means of identifying the areas of inefficiency, while also helping to formulate appropriate strategies to improve the banks' relative position on the market in an attempt to prevent systemic failures (Charles, Kumar, Zegarra, \& Avolio, 2011; Lacasta, 1988).

\section{The Argentinian Banking Sector}

In Argentina, the local practices are not far from those followed in other emerging countries: financial repression, controlled taxes, and credit directed to sectors prioritized by the political power. Ever since the mid-1970s, the banking sector has been registering several waves of liberalization; nevertheless, successive banking and macroeconomic crises have also been present. Argentina had a very high inflation rate for fifteen years starting in the mid-1970s (80-600\%) and a hyperinflation rate in 1989 and 1990 (4,000\% in the first case). After the second hyperinflation period in 1990, the system began to grow as bi-monetary, with the banks having both their assets and liabilities in US dollars.

Argentina's economy unfolded between 1991 and 2001 under the incentives provided by the regime known as the Convertibility Plan, which fixed the parity of the local currency against the US dollar. Nevertheless, midway through the period, there was a severe financial crisis caused by the Mexican devaluation in 1995 (the Tequila crisis), which involved the disappearance of many entities. Furthermore, the delays associated with the exchange rate, coupled with the diminished domestic purchasing power caused by the loss of jobs and wages, led to an exponential increase in the foreign debt after the year 1997.

At the end of this period, a new recession started to grow severely; the balance sheets of the banks deteriorated, the deposits dropped, and a process of capital flight was registered. For some economists, this was the longest recession in Argentina's history, which began in the mid-1998, at the end of Carlos Saul Menem's second term. The political climate and uncertainty regarding the presidential elections characterized this period until $24^{\text {th }}$ October 1999 , when Fernando de la Rua and Carlos Alvarez were proclaimed president and vice president of Argentina, respectively. Menem's Government left a high fiscal deficit of 7,350 million Argentinian pesos in 1999; therefore, president De La Rua took harsh measures in order to improve the finances sector; nevertheless, always considering as the very foundation of his economic program the strict maintenance of the discipline of fixed exchange rates pegged against the US dollar. This, in turn, had a negative impact on the domestic industry and especially on the export sector.

The tax increase decreed on the middle and upper classes in January 2000 was part of an overall package that sought to improve the public finances, and subsequently, the entire economy. Nevertheless, this adjustment stopped what some specialists affirmed was an incipient reactivation in the first months of the new Government, with an economic growth in the first quarter of the year. The burden of the external debt 'drowned' the Government and increased the fiscal deficit. Banks were closely linked with the national government finances, and the doubt that the state entered into receivership fed the possibility of a bank run.

The crisis reached its peak by the end of 2001, when large investors began withdrawing their monetary deposits from the banks, leading to a massive capital flight, which made the banking system to collapse. In order to protect their liquidity, banks virtually ceased to grant new loans to the private sector. In response to these incidents, a new economic policy was announced. This introduced temporary restrictions to the withdrawal of bank deposits (cash from fixed term deposits, current accounts, and savings account) - which was popularly known as "Corralito" - and the pesoization of assets and liabilities in US dollars from financial institutions. These measures deepened the economic crisis that then led to a political crisis. This caused a crisis of confidence that could not be attenuated by 
the Government, which had to declare default, as it did not have dollars or pesos to cope with the massive withdrawal of deposits. The shareholders, also, could not capitalize entities, as many of them belonged to the Government, while others suffered an asymmetric pesoization which complicated the balance sheet. On $23^{\text {rd }}$ December 2001, the sovereign debt was placed into receivership, the arrears involving sovereign bonds for US\$ 102,000 million, which became the largest debt in the modern world history (Magliano et al., 2009).

Finally, in January 2002, the convertibility scheme was abandoned and then the US dollar began to fluctuate, with an initial exchange rate of US $\$ 1=\$ 1.4$ for deposits, a rate that rose considerably in the subsequent months. The Public Emergency and Exchange System Reform law enacted on $6^{\text {th }}$ January 2002 legally determined the abandonment of convertibility. This law, together with the sharp devaluation of the Argentinian peso, marked the beginning of the promulgation of many decrees and laws - approved by the National Executive and regulated by the Central Bank - that impacted directly and indirectly on the development of the banking system.

Some of the consequences of the crisis can be described through macroeconomic variables. The Gross Domestic Product (GDP) at 1993 prices experienced a fall of 10.89\% on an average between 2001 and 2002, the GDP per capita declined by a similar percentage, and the deposits and loans (as a proportion of the GDP) suffered a decline of $0.75 \%$ and $2.83 \%$, respectively (Gonzalez Padilla, 2009).

In the early 2003, the financial sector began to recover along with the total deposits, while the total loans began to grow at constant prices only as of the next year. The economic recovery occurred regardless of the use of bank financing. The virtual disappearance of bank loans was partly due to the increase of the companies' self-financing capacity through the increased sales revenue and decreased costs. Additionally, it was also due to the fact that, initially, the banks drastically cut down on the new credits and privileged the improvement of their liquidity under conditions of high uncertainty. Although bank closures were scarce in relation to the magnitude of the crisis (Magliano et al., 2005), it is important to note that between December 2001 and December 2002, seven banks were forced to close, and in August 2010, this number had increased to 19 financial institutions, including 14 banks, which represented about $15 \%$ of the qualified entities.

After the most critical moments of the crisis, the liquidity of the banks recovered significantly and the public and cooperative banks led the supply of credit to businesses. Since 2005, the financing terms had been gradually extending the offer and began to include up to five-year loans for the purchase of machinery and equipment. Also, by the end of 2000, machinery and equipment leasing operations became significant thanks to the tax benefits.

The recovery from the crisis brought important changes in the system structure: some foreign banks - although not the large ones - gradually and voluntarily left the market since they were absorbed by the domestic banks, particularly the awardees of the privatization of official provincial banks after the Tequila crisis in 1995. In addition, the post-crisis period is characterized by a greater nationalization of banks and short-term loans and operations in Argentinian pesos. Almost all the deposits were made within one year.

In short, since the 2001 crisis and the end of the convertibility regime, "many developments have affected the financial markets where banks operate: deregulation, liberalization, globalization, and several financial and technological innovations", along with important changes in monetary and exchange rate policies from 2002, as well as the official discourse on the economic policy (Cibils \& Allami, 2008).

All of these events influenced the competitive conditions faced by the banks, i.e., the market power, the profitability and efficiency, and the stability of the financial system, which justifies a more detailed study in this regard. 
The objective of the present research study is fivefold. We employ the Data Envelopment Analysis (DEA) technique to (a) study the technical efficiency of the public banking sector in Argentina between 1998-2014, (b) compare the crises period with the non-crises period, (c) compare and contrast two different returns-to-scale, namely, constant returns-to-scale (CRS) and variable returns-to-scale (VRS), (d) rank the Argentinian public banks based on their consistency and performance over 17 years, and (e) rank the Argentinian public banks by means of applying the progressive time-weighted mean (PTWM) approach.

The remainder of the paper is organized as follows: the next two sections discuss the relevant literature on efficiency measurement in the Latin American banking sector, as well as in the Argentinian banking sector. Subsequently, the DEA technique is introduced, along with the detailed computational procedures for efficiency and PTWM approach for ranking. Next, the choice between the intermediation and the production approach in the selection of inputs and outputs is explained, followed by the results of the empirical analysis. A more detailed analysis of the political and financial crises and of the crisis-free period is also provided. The last section concludes the paper.

\section{Efficiency Measurement in the Latin American Banking Sector}

As previously mentioned, the literature is abundant in research studies measuring the efficiency and productivity of banks in developed countries (in this regard, the interested reader is further referred to the studies by Berger and Humphrey, 1997; Berger, Demsetz, and Strahan, 1999; Isik and Hassan, 2002a, 2002b; and Yildirim and Philippatos, 2007). Nevertheless, the number of studies covering Latin American countries is quite small. As a matter of fact, in a recent survey conducted by Fethi and Pasiouras (2010), who provided a comprehensive review of 179 studies focusing on assessing the bank performance, it is interesting to note that none of these studies focused on Latin American countries (Charles et al., 2011). However, there are a couple of studies that focused on efficiency measurement using both parametric frontier models (Carvallo \& Kasman, 2005; Negrin \& Guerrero, 2005) and non-parametric DEA models (Charles et al., 2011; Chortareas, Girardone, \& Garza-Garcia, 2010; Taylor, Thompson, Thrall, \& Dharmapala, 1997). The below lines briefly depict the most notable studies.

At the level of Latin America, we highlight the following research works: Rivas, Ozuna, and Policastro (2006) who studied the impact of derivatives on the efficiency of banks in Latin America; Carvallo and Kasman (2005) who estimated a common stochastic cost frontier for banks from 16 Latin American countries; Forster and Shaffer (2005) who analyzed the relationship between bank efficiency and the absolute size of Latin American banks; and Chortareas, Girardone, and Garza-Garcia (2010), who employed the technique of DEA to measure the technical and scale efficiency of the banks across nine Latin American countries between 1997 and 2005 in an endeavor to investigate the relationship between market structure, efficiency, and bank performance.

At the country level, few studies should be mentioned, as well. For the Mexican banking sector, Taylor et al. (1997), for example, applied DEA to estimate a production frontier to classify 13 public banks according to their efficiency levels. In 1999, Leon took a sample of 23 Mexican banks and employed DEA to estimate a cost frontier. The Mexican commercial banking sector was also investigated by Negrin and Guerrero (2005) who applied a stochastic frontier analysis approach to estimate static and dynamic parametric models of banking efficiency. In Chile, it is to be noted the study by Fuentes and Vergara (2007) who estimated the efficiency at the bank level through cost and profit functions. Staub, da Silva e Souza, and Tabak (2010) employed DEA to investigate the Brazilian banks between 2000 and 2007 by means of analyzing their associated cost, technical, and allocative efficiencies. Additionally, the more recent studies by Charles et al. (2011) and Charles and Kumar (2012) used the DEA technique to investigate the efficiency of Peruvian banks for the period 2000 to 2009 to benchmark existing banks based on their CRS super-efficiency scores over time and for the period 2008 to 2010 to benchmark existing banks based on their VRS super-efficiency scores over time, respectively. 


\section{Efficiency Measurement in the Argentinian Banking Sector}

Continuing with evidence from the Argentinian arena, Burdisso, Catena, and D'Amato (2001) studied the competitiveness of Argentinian banking markets. They extended the conjectural variations to companies with multiple products, which operate in two markets: retail and corporate. The authors sought to measure the degree of market power for a panel of banks from 1997 to 1999. They concluded that for both the markets, retail and corporate, the banks were very close to the competitive solution. However, they did not deepen their analysis with a specific study on efficiency. Dabos and Aromi (2001) also studied the market power of the banks and the impact that asymmetric information had on it.

Guala (2002a) assessed the Argentinian banking efficiency in the last years of the 1990s, using the cost frontier approach and the Quantile Regression Analysis method. This study covers the years with improved performance during the Convertibility period. Subsequently, Guala (2002b) evaluated the economies of scale and the scope of the Argentinian banking system during the early 1990s, following the financial reforms. Moya (2012) studied the bank productivity after the 2002 crisis, with emphasis on the distinction between public and private banks. Stagnant productivity levels were found after the year 2007.

It is essential to observe that all of these previously mentioned studies focused on analyzing the existence of a relationship between the banks' profit, the concentration, and the market power. Nevertheless, there are no specific local studies with regard to the efficiency of the banking sector.

In recent years, two studies, in particular, used the DEA technique to study the performance of the banking sector, although they did not exclusively measure the efficiency. On the one hand, Yanguas (2010) studied the behavior of the banking sector with an approach focused on the evolution of the efficiency and the market power before and after the economic crisis. It is important to mention the author's use of the structural approach which was popular in the 1990s when assessing the hypotheses regarding the 'market power' (Structure-Conduct-Performance and RMP [Relative Market Power]) and the 'structure efficiency' (X-efficiency and scale-efficiency) for all of the banks, covering the time period between 1994-2010, by using the DEA technique to obtain reliable estimates of efficiency.

On the other hand, Ferro, Leon, Romero, and Wilson (2013) studied the efficiency of the Argentinian banking system from 2005 to 2011. The analysis included the study of efficiency frontiers of the system as a whole and of subsamples of different categories of banks. Econometric and mathematical programming methods were used and consistency tests were applied. The results showed a moderate average efficiency of the system.

\section{Data Envelopment Analysis}

Built on the seminal ideas of Farrell (1957), DEA is a non-parametric benchmarking approach used to assess the relative efficiency of a set of peer entities denominated as decision-making units (DMUs) that have multiple inputs and multiple outputs (Charnes, Cooper, \& Rhodes, 1978). One of the main advantages of DEA is that it readily incorporates the existence of multiple inputs and multiple outputs without any underlying assumption of a functional form. Thus, its popularity lies within.

Ever since the introduction of the first DEA model (namely, CCR) in 1978, it has been widely used in efficiency analysis in almost every field, such as agriculture, banking, benchmarking, economy, education, environment, government, health, human resources, information technology, insurance, manufacturing, marketing, operations, public policy, regulation, retail, services, and tourism, having emerged as a powerful management science tool. 
It is to be mentioned that DEA models can be distinguished according to whether they are input-oriented (i.e., minimization of input for a given level of output) or output-oriented (i.e., maximization of output for a given level of input). In the present research paper, we employ an output-oriented DEA model to analyze the technical efficiency of Argentinian banks between 1998 and 2014.

\section{Methodology}

It is assumed that $n$ DMUs exist. Each $\operatorname{DMU}_{\mathrm{j}}(j=1,2, \ldots, n)$ consumes a vector of inputs, $x_{j}=\left(x_{1 j}, x_{2 j}, \ldots, x_{m j}\right)^{T}$ to produce a vector of outputs, $y_{j}=\left(y_{1 j}, y_{2 j}, \ldots, y_{s j}\right)^{T}$. The superscript $T$ represents the transpose. The DMU to be evaluated is designated as $\mathrm{DMU}_{0}$ and its input-output vector is denoted as $\left(x_{0}, y_{0}\right)$. Consider the following output-oriented BCC model in line with Banker, Charnes, and Cooper (1984), which involves a two-stage DEA process:

$$
\begin{aligned}
& \operatorname{Max} \phi+\varepsilon\left(\sum_{r=1}^{s} s_{r}^{+}+\sum_{i=1}^{m} s_{i}^{-}\right) \\
& \text {s.t. } \\
& \phi y_{r 0}-\sum_{j=1}^{n} y_{r j} \lambda_{j}+s_{r}^{+}=0, r=1,2, \ldots, s, \\
& \sum_{j=1}^{n} x_{i j} \lambda_{j}+s_{i}^{-}=x_{i 0}, i=1,2, \ldots, m, \\
& \sum_{j=1}^{n} \lambda_{j}=1 \\
& \lambda_{j} \geq 0, s_{r}^{+} \geq 0, s_{i}^{-} \geq 0 ; j=1,2, \ldots, n \\
& r=1,2, \ldots, s ; i=1,2, \ldots, m
\end{aligned}
$$

and $\phi$ is otherwise unconstrained. Here, $\lambda_{j}$ represents the 'structural' variables, $s_{r}^{+}$and $s_{i}^{-}$represent 'slacks' and $\varepsilon$ is a non-Archimedean infinitesimal, which is defined to be smaller than any positive real number. System (1) assumes the best-practice frontier exhibits VRS; by ignoring the convexity constraint, i.e., $\sum_{j=1}^{n} \lambda_{j}=1$ in System (1), the model becomes CRS (Charnes, Cooper, \& Rhodes, 1978). For a complete discussion on standard DEA models, refer to Cooper, Seiford, and Tone (2000).

DEA efficiency definition: $\mathrm{DMU}_{0}$ is DEA efficient if, and only if, the following two conditions are satisfied: (a) $\phi^{*}=1$ and (b) $s_{r}^{+^{*}}=s_{i}^{-*}=0, \forall i, r$, where $*$ designates an optimum.

\section{Progressive Time-Weighted Mean (Kumar \& Vincent, 2011)}

The PTWM is a method for computing a kind of weighted average of a non-empty set of numbers that gives more weight to the recent data points to make it more responsive to the new information. For the period 1 to $\tau$, let us 
consider a set of values (in our context, technical efficiency values), say $e_{t}, t=1,2, \ldots, \tau$ and associated non-negative normalized weights, say $w_{t}=2 t /\left(\tau^{2}+\tau\right), t=1,2, \ldots, \tau$. The PTWM can be defined as:

$$
\mathrm{PTWM}=\sum_{t=1}^{\tau} w_{t} e_{t}
$$

where $0<\mathrm{w}_{t}<\mathrm{w}_{t+1}, \forall t$. One can notice that more emphasis is placed on the recent data points than on the data points from the immediate past. In this study, we apply the above equation (2) to measure the mean technical efficiency scores of all of the banks during a 17-year period to find their positioning in the banking sector.

\section{The Data}

What exactly constitutes inputs and outputs in the banking sector, as well as how to measure them, represents an area of constant debate in the literature on banking (Casu \& Girardone, 2002; Sathye, 2003). Nevertheless, although there is no comprehensive theory, two main approaches regarding the measurement of inputs and outputs compete in this literature: the 'intermediation approach' and the 'production approach' (Humphrey, 1985). In the intermediation approach, banks are seen as intermediaries that use the volume of financial liabilities (mostly deposits) as inputs, to produce loans and other means of financing, as outputs. The production approach, on the other hand, treats both loans and deposits as outputs, given that deposits also provide liquidity, safekeeping, and payments services to depositors (Berger \& Humphrey, 1997). Kumar and Gulati (2008) highlighted that both approaches have their pros and cons and this is due to the fact that deposits count with both input and output characteristics, which are not easily disaggregated empirically. Berger and Humphrey (1997) suggested that the intermediation approach should be used for estimating the performance of whole banks, while the production approach should be employed for analyzing the performance of bank branches.

In the present study, following Berger and Humphrey (1997), the intermediation approach has been used with a restricted choice of variables, as opposed to the production approach for selecting inputs and outputs. A similar approach towards considering deposits as an output using an intermediation approach can be found in the study by Chen, Skully, and Brown (2005), who analyzed the cost, technical, and allocative efficiency of 43 Chinese banks over the period 1993-2000.

As such, the choice of inputs and outputs has been dictated by both the existent literature and the data availability. In the current study, one input, namely, total cost $\left(x_{1}\right)$, has been used. The input total cost is measured as the sum of total interest expenses and non-interest expenses, including personal expenses. Non-interest expenses include service charges and commissions, expenses of general management affairs, salaries, and other expenses, including health insurance and securities portfolios. Although some researchers (Kao \& Liu, 2004; Ram Mohan \& Ray, 2004; Sathye, 2003; Yeh, 1996) treated interest expenses and non-interest expenses as two different inputs, in the present study we have followed the path of Casu and Molyneux (2003), Sealey and Lindley (1977), and Udhayakumar, Charles, and Kumar (2011) and, therefore, treated both expenses as one single input. The reason behind such treatment lies in the fact that when there is a high number of variables relative to the number of observations, the risk is that more units will tend to be wrongly identified as efficient. When too many constraints are specified, the observations tend to become incomparable (Zhao, Casu, \& Ferrari, 2008). The above input is used to produce three outputs: total loans $\left(y_{1}\right)$, total deposits $\left(y_{2}\right)$, and other earning assets (OEA) $\left(y_{3}\right)$. The output 'total loans' is measured as the sum of all of the loan accounts intermediated by banks; the output 'total deposits' is taken as the sum of demand and savings deposits held by the bank and non-bank depositors; and the output 'OEA' $\left(y_{3}\right)$ is measured as the sum of total securities (treasury bills, government bonds, and other securities), deposits with banks, and equity investments. 
An isotonicity test (Avkiran, 1999), involving the calculation of all inter-correlations between inputs and outputs to identify whether increasing amounts of inputs lead to greater outputs, was performed to ensure the validity of the DEA model specification and to justify the inclusion of inputs and outputs. As the inter-correlation between the input and outputs was deemed to be positive (Pearson correlations $>0.90 ; \alpha=0.01$ ), the isotonicity test was passed.

The basic data on inputs and outputs have been taken from the bulletins published on a regular basis by the Central Bank of Argentina (BCRA), which include detailed balance sheets of every institution. The sample consists of all of the public banks in Argentina during the period spanning 1998 to 2014. As such, 14 banks are included; at any point in time, data for at least 11 banks and at most 13 banks were incorporated in the analysis.

Regarding the number of DMUs, it is quite clear that there are advantages to having larger data sets; nevertheless, the literature indicates some minimum requirements, as well. For example, Golany and Roll (1989) and Homburg (2001) suggested that the number of DMUs should be at least twice the number of inputs and outputs. Nunamaker (1985) and Raab and Lichty (2002), on the other hand, suggested that there should be three times the number of DMUs as there are inputs and outputs. In this study, with a total of one input and three outputs, a minimum sample size ranging between 8 and 12 was required. However, as Cook, Tone, and Zhu (2014) pointed out, whereas in statistical regression analysis, sample size is a vital issue - as it tries to estimate the average behavior of a set of DMUs -, when used as a benchmarking tool, DEA focuses on the performance of each DMU, and as such, the sample size or the number of DMUs being evaluated may be immaterial. Summary statistics of both inputs and outputs for the Argentinian banks for each year under study is available from the authors.

\section{Results and Discussion}

When analyzing the trend of the CRS efficiency indices (see Appendix A), two significant drops in the efficiency levels can be observed during the 1998-2014 period. They correspond to both a political change (as the presidential elections were held in 1999) and the economic and financial crisis of 2001-2002. This can also be appreciated in the levels of the coefficient of variation (CV), which record very high values in the two specific years: $96 \%$ in 1999 and $145 \%$ in 2002. Thus, this indicates that the technical efficiencies of the banks were not consistent in those years when compared to the other years. With respect to the average efficiency of the public banks, in 1999 this was 0.2490 and in 2002 it was 0.2020 . It is interesting to note that the lowest overall average efficiency was recorded in 2002 (0.2020); however, the recovery that took place the very next year, in 2003, translated into the highest average efficiency (0.7391) for the entire period of study.

The trend of the VRS efficiency indices during the 1998-2014 period (see Appendix B) also indicates two significant declines in the efficiency levels of the public banks: in 1999 and in 2002. While the levels of the CV once again record high value for these two years, the assumed values are lower than those obtained under the CRS approach: 75\% in 1999 and 61\% in 2002, which shows that the technical efficiencies of the banks were less consistent in 1999 as a result of the political situation in the country. With respect to the average efficiency of the public banks, these values were also higher than those obtained under CRS: 0.4958 in 1999 and 0.6276 in 2002 .

Furthermore, it has been found that there is a high positive correlation (0.867) between CRS and VRS across the period of study. The paired t-test statistic $(t=-7.372 ; \mathrm{df}=16 ; p=0.000)$ reveals with a 5\% level of significance that the VRS technical efficiency is not less than the CRS technical efficiency (paired mean difference of -0.15 with standard error 0.0204), which is clearly seen in Figure 1. 


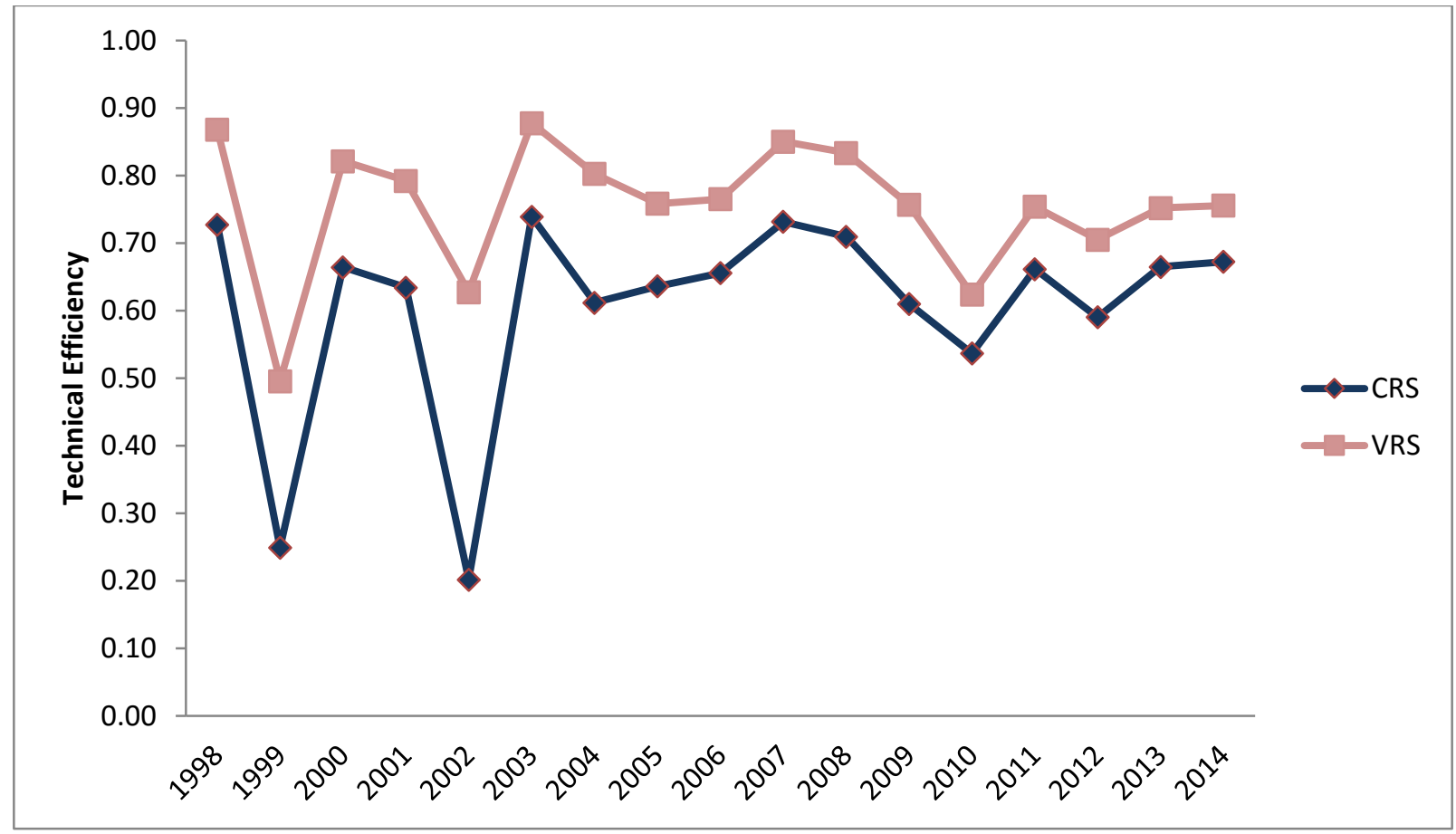

Figure 1. Trends of CRS and VRS.

By performing an individual analysis of the banks under the CRS technology (see Appendix A), it can be observed that Banco de la Nación Argentina registered a substantial fall during 1999, and it was also affected - like the rest of the public banks - in 2002. Then, this bank achieved high efficiency levels, which were maintained until 2014 with little variation. One of the noteworthy insights is that Banco de la Ciudad de Buenos Aires was the only bank to maintain good levels of efficiency during the political change of 1999. By contrast, Banco del Chubut S.A. was affected by the political crisis of 1999, but it did not suffer the fall of the other public banks in 2002. Another bank with similar performance is Banco de La Pampa, which suffered a slight decrease in efficiency in 2002, although less than the other public banks. The bank that was affected the most and suffered the greatest fall was Banco Municipal del Rosario (with an average efficiency of 0.0672 in 1999 and 0.0395 in 2002).

An individual analysis of the banks under the VRS technology (see Appendix B) reveals that their performance was quite similar during the time period, with more entities (such as Banco de la Ciudad de Buenos Aires and Banco de la Nación Argentina) having sustained high efficiency levels during the time period or having slight variations. It is interesting to note, however, that while Banco Municipal del Rosario maintained a high level of efficiency during the political crisis of 1999, during the economic and financial crisis of 2002, the same bank was the one that registered the greatest fall among all the banks. Equally remarkable is the bank's immediate recovery during the very next year, which was then able to maintain for seven years until 2010. Interesting, as well, is the case of Banco del Chubut S.A., which had an important fall during 1999, but did not suffer the fall of other banks in 2002. The two banks that suffered the most during both 1999 and 2002 were Banco Municipal de la Plata and Banco Provincia de Tierra del Fuego. 
It is probably most notable the case of Banco Municipal de la Plata, which was strongly affected by the both the crises and which exited the market in 2003.

Table 1 below provides the summary of the bank-wise mean and PTWM efficiency scores, for the entire period of study. The CV values are also reported along with the efficiency scores in order to observe the consistency in efficiency across the banks. The information provided in Table 1 can be graphically appreciated in Figure 2 .

Table 1

Analytics of Efficiency Derived from CRS and VRS

\begin{tabular}{|c|c|c|c|c|c|c|c|}
\hline & & \multicolumn{3}{|c|}{ VRS } & \multicolumn{3}{|c|}{ CRS } \\
\hline $\mathbf{N}^{\circ}$ & Bank & Mean & $\mathbf{C V}$ & PTWM & Mean & $\mathbf{C V}$ & PTWM \\
\hline 1 & Banco de Corrientes S.A. & 0.6041 & 0.3638 & 0.5902 & 0.4888 & 0.3382 & 0.4926 \\
\hline 2 & $\begin{array}{l}\text { Banco de Inversión y Com. Ext. } \\
\text { S.A. }\end{array}$ & 1.0000 & 0.0000 & 1.0000 & 1.0000 & 0.0000 & 1.0000 \\
\hline 3 & $\begin{array}{l}\text { Banco de la Ciudad de Buenos } \\
\text { Aires }\end{array}$ & 0.9960 & 0.0103 & 0.9990 & 0.8786 & 0.2568 & 0.8925 \\
\hline 4 & Banco de la Nación Argentina & 1.0000 & 0.0000 & 1.0000 & 0.8637 & 0.3167 & 0.9206 \\
\hline 5 & Banco de La Pampa & 0.6891 & 0.2736 & 0.6526 & 0.6126 & 0.3046 & 0.5970 \\
\hline 6 & $\begin{array}{l}\text { Banco de la Provincia de Buenos } \\
\text { As. }\end{array}$ & 0.7220 & 0.2297 & 0.6630 & 0.5791 & 0.3515 & 0.5714 \\
\hline 7 & $\begin{array}{l}\text { Banco de la Provincia de } \\
\text { Córdoba }\end{array}$ & 0.6210 & 0.3273 & 0.5788 & 0.5226 & 0.4165 & 0.5121 \\
\hline 8 & Banco del Chubut S.A. & 0.8370 & 0.2989 & 0.8571 & 0.7382 & 0.3366 & 0.7599 \\
\hline 9 & Banco Municipal de La Plata & 0.4692 & 0.6487 & 0.0396 & 0.3333 & 0.6877 & 0.0271 \\
\hline 10 & Banco Municipal de Rosario & 0.8730 & 0.2941 & 0.8519 & 0.3588 & 0.3935 & 0.4042 \\
\hline 11 & $\begin{array}{l}\text { Banco Provincia de Tierra del } \\
\text { Fuego }\end{array}$ & 0.8262 & 0.3595 & 0.8953 & 0.5650 & 0.3544 & 0.6021 \\
\hline 12 & $\begin{array}{l}\text { Banco Provincia del Neuquén } \\
\text { S.A. }\end{array}$ & 0.6013 & 0.3462 & 0.5844 & 0.5293 & 0.4256 & 0.5215 \\
\hline 13 & Nuevo Banco Bisel S.A. & 0.5923 & 0.2514 & 0.1603 & 0.4537 & 0.4608 & 0.1297 \\
\hline 14 & Nuevo Banco del Chaco S.A. & 0.6007 & 0.4041 & 0.5734 & 0.5085 & 0.3970 & 0.5082 \\
\hline
\end{tabular}

The similarity of values obtained was tested. The rank correlation between CV of VRS and CRS is highly positively correlated, with the Spearman correlation coefficient of 0.644 (Kendall tau (b) 0.495). The rank correlation between the means of VRS and CRS is highly positively correlated, with the Spearman correlation coefficient of 0.758 (Kendall tau (b) 0.648). Furthermore, the rank correlation between the weighted average of VRS and CRS is highly positively correlated, with the Spearman correlation coefficient of 0.873 (Kendall tau (b) 0.758). 


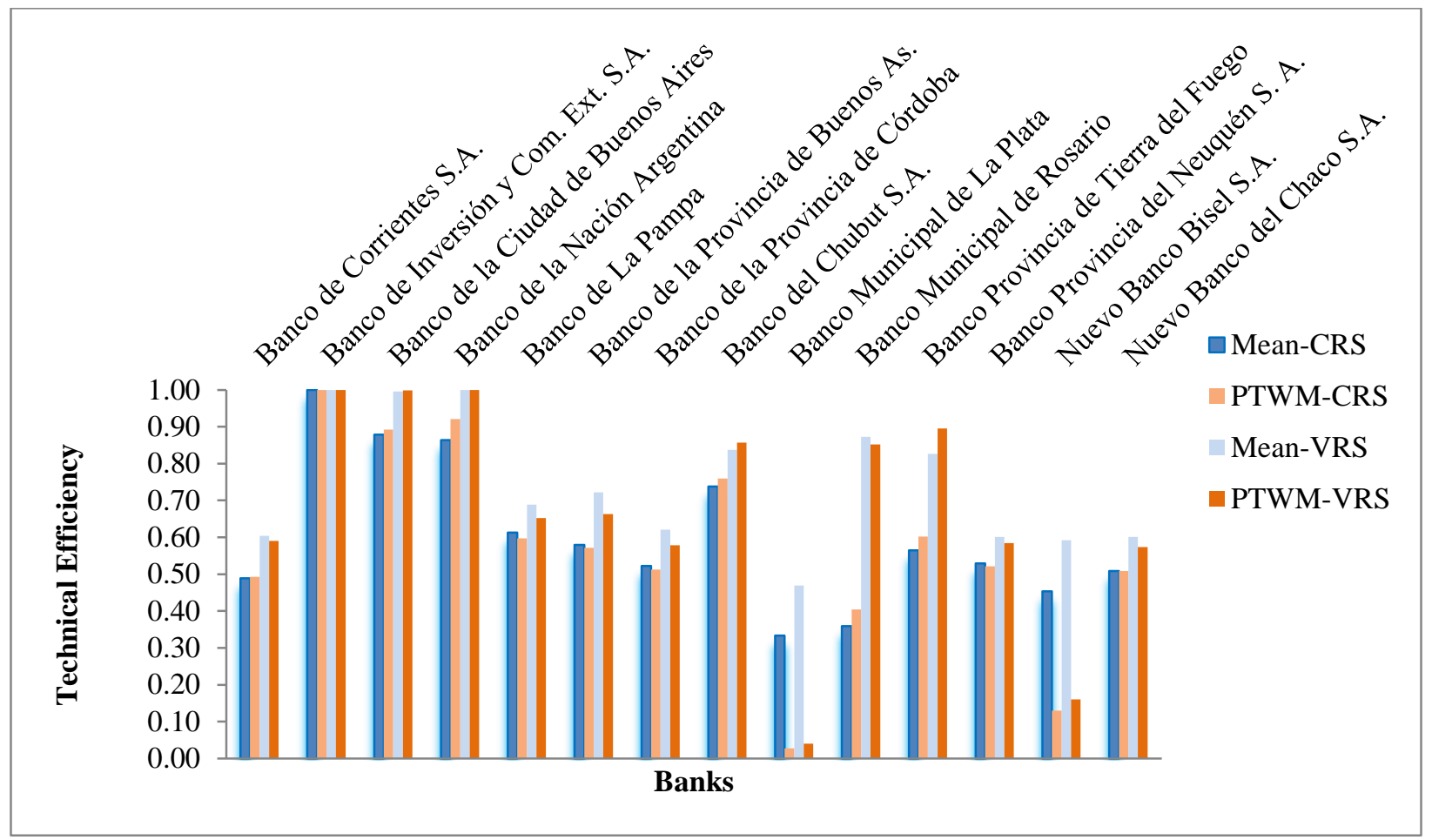

Figure 2. Mean technical efficiency of public banks.

It can be observed that Banco de Inversión y Com. Ext. S.A., Banco de la Ciudad de Buenos Aires, and Banco de la Nación Argentina were the banks to have registered the highest efficiency levels throughout the entire period of study, under both the CRS and VRS technologies, with slight variations for the last two banks.

By contrast, Banco Municipal de la Plata was the worst performer under both the technologies, with extremely low values under the PTWM approach, fact that can be explained by the bank's exit from the market in 2003. A similar phenomenon can be observed in the case of Nuevo Banco Bisel S.A., which exited the market in 2007.

As initially proposed, the existing public banks are ranked based on their CRS and VRS performance over the entire period of study by applying: (a) the mean, (b) the CV, and (c) the PTWM approach (Kumar \& Vincent, 2011). Thus, Table 2 reports the position of the banks in the public banking sector.

As it can be observed, Banco de Inversión y Com. Ext. S.A. is the best performer based on the PTWM method in both CRS and VRS technologies, and since the technical efficiency is very consistent, the bank is positioned as $1^{\text {st }}$ even based on the simple average approach.

Banco de la Nación Argentina is the second best performer based on the PTWM method in both CRS and VRS technologies; however, the consistency of the technical efficiency is slightly better in VRS than in CRS, which can be seen through the positioning of the bank as $2^{\text {nd }}$ and $3^{\text {rd }}$ based on the simple average method. A similar analysis stands for the case of Banco de la Ciudad de Buenos Aires. 
Table 2

Rank Order Derived from the Technical Efficiency

\begin{tabular}{clcccccc}
\hline & & \multicolumn{3}{c}{ VRS } & \multicolumn{3}{c}{ CRS } \\
\hline $\mathbf{N}^{\circ}$ & Bank & Mean & CV & PTWM & Mean & CV & PTWM \\
\hline 1 & Banco de Corrientes S.A. & 10 & 11 & 9 & 11 & 6 & 11 \\
2 & Banco de Inversión y Com. Ext. S.A. & 1 & 1 & 1 & 1 & 1 & 1 \\
3 & Banco de la Ciudad de Buenos Aires & 3 & 3 & 3 & 2 & 2 & 3 \\
4 & Banco de la Nación Argentina & 2 & 2 & 2 & 3 & 4 & 2 \\
5 & Banco de La Pampa & 8 & 5 & 8 & 5 & 3 & 6 \\
6 & Banco de la Provincia de Buenos As. & 7 & 4 & 7 & 6 & 7 & 7 \\
7 & Banco de la Provincia de Córdoba & 9 & 8 & 11 & 9 & 11 & 9 \\
8 & Banco del Chubut S.A. & 5 & 7 & 5 & 4 & 5 & 4 \\
9 & Banco Municipal de La Plata & $\mathrm{x}$ & $\mathrm{x}$ & $\mathrm{x}$ & $\mathrm{x}$ & $\mathrm{x}$ & $\mathrm{x}$ \\
10 & Banco Municipal de Rosario & 4 & 6 & 6 & 12 & 9 & 12 \\
11 & Banco Provincia de Tierra del Fuego & 6 & 10 & 4 & 7 & 8 & 5 \\
12 & Banco Provincia del Neuquén S. A. & 11 & 9 & 10 & 8 & 12 & 8 \\
13 & Nuevo Banco Bisel S.A. & $\mathrm{x}$ & $\mathrm{x}$ & $\mathrm{x}$ & $\mathrm{x}$ & $\mathrm{x}$ & $\mathrm{x}$ \\
14 & Nuevo Banco del Chaco S.A. & 12 & 12 & 12 & 10 & 10 & 10 \\
\hline
\end{tabular}

Note. The $\mathrm{x}$ indicates that since the bank exited the market, it cannot be a part of the current rank.

Nuevo Banco del Chaco S.A., on the other hand, is the worst performer, ranked as $12^{\text {th }}$ by the VRS method and $10^{\text {th }}$ by the CRS method. However, it is interesting to note that the bank's technical efficiency is not consistent when compared with all the other existing banks.

\section{Analysis of the Political and Economic and Financial Crises and of the Crisis-Free Period}

From the analysis of the CRS efficiency levels during 1999 (characterized by a political crisis), 2002 (characterized by an economic and financial crisis), and the years without a crisis, it can be noted, that in general, the average efficiency level of the public banks was slightly higher in 1999 (0.2490) than in $2002(0.2020)$. However, it is worth to point out that Banco de la Pampa and Banco del Chubut S.A. were the only two banks that were affected more by the political situation of 1999 than by the economic and financial crisis of 2002 (see Table 3, also Figure 3 for a pictorial representation); all this while the other banks decreased their performance more remarkably because of the economic and financial crisis.

Table 3

CRS Technical Efficiency during the Crises Period versus Other Years

\begin{tabular}{rlrrrr}
\hline $\mathbf{N}^{\circ}$ & Bank & $\mathbf{1 9 9 9}$ & $\mathbf{2 0 0 2}$ & $\begin{array}{r}\text { Other } \\
\text { Years }\end{array}$ & $\begin{array}{r}\text { Difference } \\
\mathbf{1 9 9 9 - 2 0 0 2}\end{array}$ \\
\hline 1 & Banco de Corrientes S.A. & 0.1698 & 0.1229 & 0.5345 & 0.0469 \\
2 & Banco de Inversión y Com. Ext. S.A. & & & 1.0000 & 0.0000 \\
3 & Banco de la Ciudad de Buenos Aires & 1.0000 & 0.0873 & 0.9232 & 0.9127 \\
\hline
\end{tabular}


Table 3 (cont.)

CRS Technical Efficiency during the Crises Period versus Other Years

\begin{tabular}{clrrrr}
\hline $\mathbf{N}^{\circ}$ & Bank & $\mathbf{1 9 9 9}$ & $\mathbf{2 0 0 2}$ & $\begin{array}{r}\text { Other } \\
\text { Years }\end{array}$ & $\begin{array}{r}\text { Difference } \\
\mathbf{1 9 9 9 - 2 0 0 2}\end{array}$ \\
\hline 4 & Banco de la Nación Argentina & 0.2667 & 0.0784 & 0.9559 & 0.1883 \\
5 & Banco de La Pampa & 0.1912 & 0.6849 & 0.6359 & -0.4937 \\
6 & Banco de la Provincia de Buenos As. & 0.2421 & 0.0898 & 0.6342 & 0.1524 \\
7 & Banco de la Provincia de Córdoba & 0.1376 & 0.1212 & 0.5751 & 0.0163 \\
8 & Banco del Chubut S.A. & 0.1524 & 1.0000 & 0.7598 & -0.8476 \\
9 & Banco Municipal de La Plata & 0.1305 & 0.0792 & 0.4856 & 0.0513 \\
10 & Banco Municipal de Rosario & 0.0672 & 0.0395 & 0.3996 & 0.0277 \\
11 & Banco Provincia de Tierra del Fuego & 0.2212 & 0.0914 & 0.6195 & 0.1298 \\
12 & Banco Provincia del Neuquén S. A. & 0.1792 & 0.0810 & 0.5825 & 0.0982 \\
13 & Nuevo Banco Bisel S.A. & 0.3788 & 0.0888 & 0.5270 & 0.2900 \\
14 & Nuevo Banco del Chaco S.A. & 0.0996 & 0.0623 & 0.5655 & 0.0373 \\
\hline & Mean & 0.2490 & 0.2020 & 0.6570 & \\
& Standard Deviation & 0.2394 & 0.2922 & 0.1838 & \\
& CV & $96 \%$ & $145 \%$ & $28 \%$ & \\
\hline
\end{tabular}

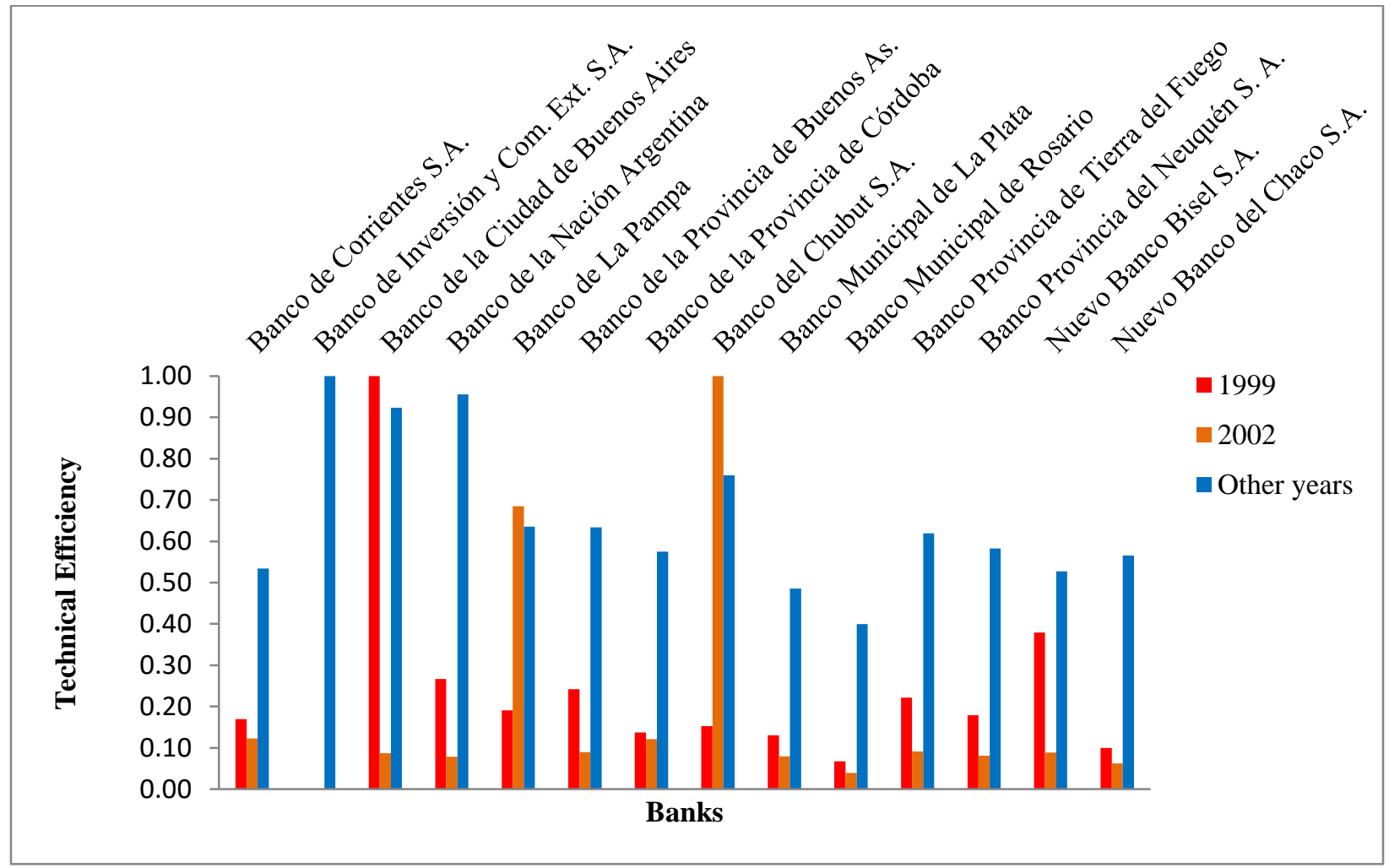

Figure 3. CRS technical efficiency during the crises period versus other years. 
On a different note, Banco de Inversión y Com. Ext. S.A. entered the market in 2010, which is why no efficiency scores are displayed for this bank during the crises period. It can also be observed that, in general, the highest technical efficiency was achieved during the non-crises period, with three exceptions: Banco de la Ciudad de Buenos Aires Argentina - that registered its highest efficiency score during the political crisis of 1999, and Banco de la Pampa and Banco del Chubut S.A. - that reached their highest efficiency during the economic and financial crisis of 2002.

With regard to the VRS efficiency levels during 1999, 2002, and the years without a crisis, it is worth to point out that nine public banks were affected more by the political situation of 1999 than by the economic and financial crisis of 2002 (see Table 4, also Figure 4 for a pictorial representation). In this case, the average efficiency level of the public banks was higher in 2002 (0.6276) than in 1999 (0.4958).

Table 4

VRS Technical Efficiency during the Crises Period versus Other Years

\begin{tabular}{clrrrr}
\hline $\mathbf{N}^{\circ}$ & Bank & $\mathbf{1 9 9 9}$ & $\mathbf{2 0 0 2}$ & $\begin{array}{r}\text { Other } \\
\text { Years }\end{array}$ & $\begin{array}{r}\text { Difference } \\
\mathbf{1 9 9 9 - 2 0 0 2}\end{array}$ \\
\hline 1 & Banco de Corrientes S.A. & 0.2370 & 0.2793 & 0.6502 & -0.0424 \\
2 & Banco de Inversión y Com. Ext. S.A. & & & 1.0000 & 0.0000 \\
3 & Banco de la Ciudad de Buenos Aires & 1.0000 & 1.0000 & 0.9955 & 0.0000 \\
4 & Banco de la Nación Argentina & 1.0000 & 1.0000 & 1.0000 & 0.0000 \\
5 & Banco de La Pampa & 0.3497 & 1.0000 & 0.6910 & -0.6503 \\
6 & Banco de la Provincia de Buenos As. & 0.9709 & 1.0000 & 0.6868 & -0.0291 \\
7 & Banco de la Provincia de Córdoba & 0.3937 & 1.0000 & 0.6109 & -0.6063 \\
8 & Banco del Chubut S.A. & 0.1828 & 1.0000 & 0.8697 & -0.8172 \\
9 & Banco Municipal de La Plata & 0.1416 & 0.2320 & 0.6574 & -0.0904 \\
10 & Banco Municipal de Rosario & 1.0000 & 0.1040 & 0.9158 & 0.8960 \\
11 & Banco Provincia de Tierra del Fuego & 0.2212 & 0.1905 & 0.9089 & 0.0308 \\
12 & Banco Provincia del Neuquén S. A. & 0.1815 & 0.4405 & 0.6401 & -0.2590 \\
13 & Nuevo Banco Bisel S.A. & 0.6410 & 0.6803 & 0.5696 & -0.0392 \\
14 & Nuevo Banco del Chaco S.A. & 0.1261 & 0.2326 & 0.6569 & -0.1065 \\
\hline & Mean & 0.4958 & 0.6276 & 0.7752 & \\
& Standard Deviation & 0.3700 & 0.3839 & 0.1622 & \\
& CV & $75 \%$ & $61 \%$ & $21 \%$ & \\
\hline
\end{tabular}

It is in this context that Banco Municipal del Rosario and Banco Provincia de Tierra del Fuego are the only two banks that were affected more by the economic and financial crisis of 2002 than by the political crisis of 1999 . Once again, no efficiency scores are calculated for Banco de Inversión y Com. Ext. S.A., as this bank entered the market in 2010 .

It is interesting to note that among the 14 banks analyzed, seven banks achieved their highest efficiency during the non-crises period, while the other remaining seven banks achieved their highest efficiency score during the crises period. Among the latter, five banks achieved their highest efficiency during the economic and financial crisis of 2002 and only one bank (Banco Municipal del Rosario) reached its highest efficiency during the political crisis of 
1999). Lastly, one bank (Banco de la Ciudad de Buenos Aires) experienced similar levels of efficiency during both 1999 and 2002.

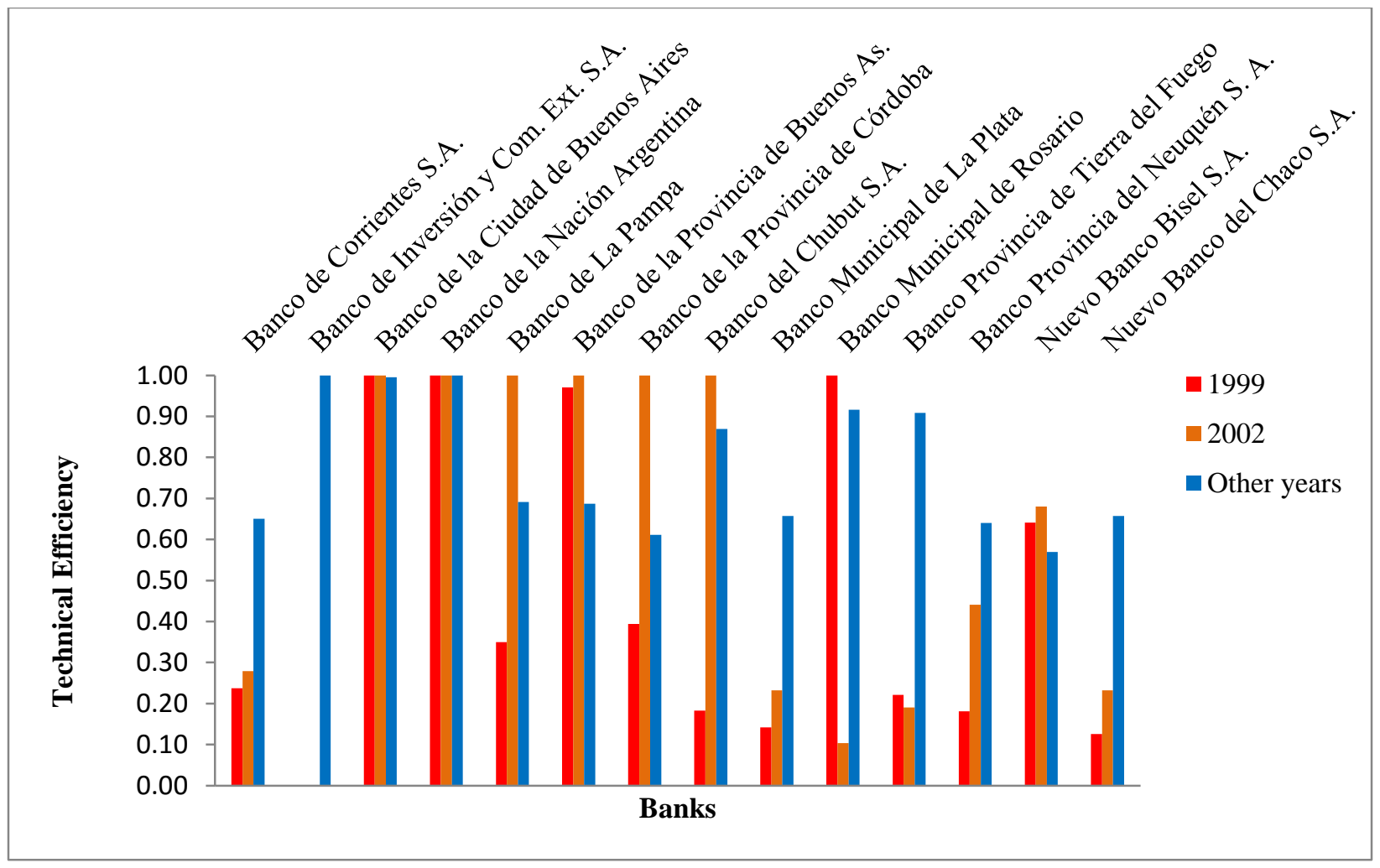

Figure 4. VRS technical efficiency during the crises period versus other years.

\section{Conclusion}

The performance of the banking sector has always been of interest, especially to policy makers, since banks in general are considered to be a key component of a country's development prospects. In this study, the DEA technique was used to measure the efficiency of the Argentinian public banks following both the CRS and VRS technologies. In addition, a comparative assessment of the existing banks was performed in the pre- and post-crises period of 1999 and 2001-2002, based on the PTWM method proposed by Kumar \& Vincent (2011). On average, the technical efficiency shows a sharp drop in both 1999 and 2002, which could be attributable to the political and economic and financial crises, respectively; furthermore, the banks achieved high efficiency levels for the rest of the period, which were maintained until 2014 with little variation.

An in-depth individual analysis of the existing banks in the recent years of the period under discussion shows that the efficiency scores are consistent in the case of the best performers. Among the 14 existing banks, Banco de Inversión y Com. Ext. S.A., Banco de la Nación Argentina, and Banco de la Ciudad de Buenos Aires were the best performers under both the CRS and VRS technologies and under both the PTWM and simple average approaches. This result can be explained by the fact that the technical efficiency is very consistent. In the case of the worst performers, on the other hand, efficiency scores are less consistent. Under the VRS technology, Nuevo Banco del 
Chaco S.A. is the worst performer (ranked as 12th), a result which is confirmed even by the simple average method in the context of a high CV that indicates less consistency; however, under the CRS technology, the same bank is ranked as 10th by both the methods - classifying Banco Municipal del Rosario as the worst performer.

Overall, the present research study contributes to the body of literature on banking efficiency with evidence from the Argentinian arena and provides empirical information that concerned authorities may use in deliberations regarding future reform policies. Future research endeavours may consider identifying and exploring the factors that affect the performance of the Argentinian banking sector, as well as expanding the analysis to include private banks, as well.

\section{References}

Avkiran, N. K (1999). Productivity analysis in the services sector with data envelopment analysis (1st ed.). Camira, Queensland: NK Avkiran.

Banker, R. D., Charnes, A., \& Cooper, W. W. (1984). Some models for estimating technical and scale efficiencies in Data Envelopment Analysis. Management Science, 30, 1078-1092.

Barros, C. P., Managi, S., \& Matousek, R. (2012). The technical efficiency of the Japanese banks: Non-radial directional performance measurement with undesirable output. Omega: The International Journal of Management Science, 40(1), 1-8.

Berger, A. N., \& Humphrey, D. B. (1997). Efficiency of financial institutions: International survey and directions for future research. European Journal of Operational Research, 98(2), 175-212.

Berger, A. N., Demsetz, R. S., \& Strahan, P. E. (1999). The consolidation of the financial services industry: Causes, consequences, and implications for the future. Journal of Banking \& Finance, 23, 135-194.

Berger, A. N., Leusner, J. H., \& Mingo, J. J. (1997). The efficiency of bank branches. Journal of Monetary Economics, 40(1), 141-162.

Burdisso, T.; Catena, M. \& D'Amato, L. (2001) Bank Competition in Argentina: 1997-1999). BCRA Working Paper (20). Argentina.

Carvallo, O., \& Kasman, A. (2005). Cost efficiency in the Latin American and Caribbean banking systems. International Financial Markets, Institutions and Money, 15, 55-72.

Casu, B., \& Girardone, C. (2002). A comparative study of the cost efficiency of Italian bank conglomerates. Managerial Finance, 28(9), 3-23.

Casu, B., \& Molyneux, P. (2003). A comparative study of efficiency in European banking. Applied Economics, 35(17), 1865-1876.

Charles, V., \& Kumar, M. (2012). Ranking of Peruvian Banks through Super Efficiency DEA Model under Cariables-Return-to-Scale (Chapter 7). In V. Charles \& M. Kumar (Eds.), Data Envelopment Analysis and Its Applications for Management (pp. 116-135). England, UK: Cambridge Scholars Publishing.

Charles, V., Kumar, M., Zegarra, F., \& Avolio, B. (2011). Benchmarking Peruvian banks using data envelopment analysis. Journal of CENTRUM Cathedra (JCC): The Business and Economics Research Journal, 4(2), 147164.

Charnes, A., Cooper, W. W., \& Rhodes, E. (1978). Measuring the efficiency of decision making units. European Journal of Operational Research, 2(6), 429-444.

Chen, X., Skully, M., \& Brown, K. (2005). Banking efficiency in China: Application of DEA to pre- and postderegulation eras: 1993-2000. China Economic Review, 16(3), 229-245.

Chortareas, G. E., Girardone, C., \& Garza-Garcia, J. G. (2010). Banking Sector Performance in Latin America: Market Power versus Efficiency (Working Papers 2010-20). Mexico, D. F., Mexico: Banco de Mexico. 
Cibils, A., \& y Allami, C. (2008). El sistema financiero argentino desde la reforma de 1977 hasta la actualidad: rupturas y continuidades. XXI Jornadas de Historia Económica. Asosiación Argentina de Historia Económica. Setiembre de 2008, http://xxijhe.fahce.unlp.edu.ar/

Cook, W. D., Tone, K., \& Zhu, J. (2014). Data envelopment analysis: prior to choosing a model. Omega: The International Journal of Management Science, 44, 1-4.

Cooper, W. W., Seiford, L. M., \& Tone, K. (2000). Data envelopment analysis: A comprehensive reference text with models, applications, references, and DEA-Solver Software. Boston, MA: Kluwer Academic.

Dabos, M. \& Aromí, D. (2001) Measuring the level of competition in the Argentine banking industry. Documento de Trabajo (34), Departamento de Economía, Universidad de San Andrés, Argentina.

Farrell, M. J. (1957). The measurement of productive efficiency. Journal of the Royal Statistical Society, 120(3), 253-281.

Ferro, G.; León, S.; Romero, C. \& Wilson, D. (2013) Eficiencia del Sistema Bancario Argentino (2005-2011). Anales de la Asociación Argentina de Economía Política, XLVIII Reunión Anual. Argentina.

Fethi, M. D., \& Pasiouras, F. (2010). Assessing Bank Efficiency and Performance with Operational Research and Artificial Intelligence Techniques: A Survey. European Journal of Operational Research, 204(2), 189-198.

Forster, J., \& Shaffer, S. (2005). Bank efficiency in Latin America. Applied Economics Letters, 12(9), 529-532.

Fuentes, R., \& Vergara, M. (2007). Is ownership structure a determinant of bank efficiency? (Working Paper No. 456). Santiago de Chile, Chile: Central Bank of Chile.

Golany, B., \& Roll, Y. (1989). An application procedure for DEA. Omega. 17(3), 237-250.

Gonzalez Padilla, H. G. (2009) Una Evaluación de la Competencia en el Sector Bancario de Argentina: Evidencia Empírica con Datos a Nivel de Banco. BCRA Working Paper (49). Argentina.

Guala, F. (2002 a). Evaluating Bank Efficiency Using Cost Frontier and Quantile Regression Analysis: The Case of Argentina in the Late 1990s. University of Illinois at Urbana Champaign Department of Economics Working Paper.

Guala, F. (2002 b). Measuring Economies of Scale and Scope For the Argentine Bank Industry: A Comparative Analysis, 1996-1999. University of Illinois at Urbana Champaign Department of Economics Working Paper.

Homburg, C. (2001). Using data envelopment analysis to benchmark activities. International Journal of Production Economics, 73(1), 51-58.

Humphrey, D. B. (1985). Costs and scale economies in bank intermediation. In R.C. Aspinwall \& R.A. Eisenbeis (Eds.), Handbook for Banking Strategy (pp. 745-783). New York, NY: John Wiley and Sons.

Isik, I., \& Hassan, M. K. (2002a). Technical, scale and allocative efficiencies of the Turkish banking industry. Journal of Banking \& Finance, 26(4), 719-766.

Isik, I., \& Hassan, M. K. (2002b). Cost and profit efficiency of the Turkish banking industry: an empirical investigation. The Financial Review, 37(2), 257-279.

Kao, C., \& Liu, S. (2004). Predicting bank performance with financial forecasts: A case of Taiwan commercial banks. Journal of Banking \& Finance, 28(10), 2353-2368.

Kumar, S., \& Gulati, R. (2008). Evaluation of technical efficiency and ranking of public sector banks in India: An analysis from cross-sectional perspective. International Journal of Productivity and Performance Management, 57(7), 540-568.

Kumar, M., \& Vincent, C. (2011). Benchmarking Indian banks using DEA in post-reform period: a progressive-time weighted mean approach. The Service Industries Journal, 14(1), 2455-2485.

Lacasta, I. (1988). Risk and recent evolution of banking system: A case study of Spain (Research Paper in Banking and Finance Report No. 88/9). London, UK: Institute of European Finance.

Leon, C. J. (1999). Cost efficiency of commercial banks in Mexico: An application of a nonparametric approximation to DEA (Memo). Ohio, Territory: Ohio State University. 
Magliano, A. C., Arrigoni, M. Á., Heller, C., Elespe, D., Goity, G., Perrotta, D., \& otros. (2005). La recuperación del Sistema Financiero Argentino. Editorial A. Liska. Buenos Aires: GRUPO SOL COMUNICACIONES S.A.

Mishkin, S. F., \& Eakins,, S. (2014). Financial Markets and Institutions. Boston, MA: Prentice Hall.

Moya, R. (2012). Productividad del sistema financiero argentino: ¿son los bancos públicos eficientes? Documento de Trabajo $N^{\circ}$ 117. FIEL. Buenos Aires.

Negrin, J. L., \& Guerrero, R. (2005). Eficiencia del Sistema Bancario Mexicano 1997-2002: una estimacion dinamica. Monetaria, 29(3), 235-259.

Nunamaker, T. R. (1985). Using data envelopment analysis to measure the efficiency of non-profit organizations: A critical evaluation. Managerial and Decision Economics, 6(1), 50-58.

Paradi, J. C., Zhu, H., \& Edelstein, B. (2012). Identifying managerial groups in a large Canadian bank branch network with a DEA approach. European Journal of Operational Research, 219(1), 178-187.

Pou, P. (March, 2000). Argentina's Structural Reforms of the 1990s. Finance \& Development, 37(1). Retrieved from http://www.imf.org/external/pubs/ft/fandd/2000/03/pou.htm

Raab, R., \& Lichty, R. (2002). Identifying sub-areas that comprise a greater metropolitan area: The criterion of country relative efficiency. Journal of Regional Science, 42(3), 579-594.

Ram Mohan, T. T., \& Ray, S. C. (2004). Productivity growth and efficiency in Indian banking: A comparison of public, private, and foreign banks (Economics Working Paper). Department of Economics, University of Connecticut.

Rivas, A., Ozuna, T., \& Policastro, F. (2006). Does the use of derivatives increase bank efficiency? Evidence from Latin American banks. International Business and Economics Research Journal, 5(11), 47-56.

Sathye, M. (2003). Efficiency of banks in a developing economy: The case of India. European Journal of Operational Research, 148(3), 662-671.

Sealey, C. W. Jr., \& Lindley, J. T. (1977). Inputs, outputs, and a theory of production and cost at depository financial institutions. Journal of Finance, 32(4), 1251-1266.

Staub, R. B., da Silva e Souza, G., \& Tabak, B. M. (2010). Evolution of bank efficiency in Brazil: A DEA approach. European Journal of Operational Research, 202(1), 204-213.

Taylor, W. M., Thompson, R. G., Thrall, R. M., \& Dharmapala, P. S. (1997). DEA/AR efficiency and profitability of Mexican banks: A total income model. European Journal of Operations Research, 98(2), 346-363.

The Heritage Foundation. (2015). 2015 Index of Economic Freedom. Argentina. Retrieved from http://www.heritage.org/index/country/argentina

Tsolas, I. E., \& Charles, V. (2015). Incorporating risk into bank efficiency: A satisficing DEA approach to assess the Greek banking crisis. Expert Systems with Applications, 42(7), 3491-3500.

Udhayakumar, A., Charles, V., \& Kumar, M. (2011). Stochastic simulation based genetic algorithm for chance constrained data envelopment analysis problems. Omega, 39(4), 387-397.

Yanguas, María Lucía (2010) Eficiencia y Poder de Mercado en el Sector Financiero: el caso Argentino. Tesis de Licenciatura en Economía, Universidad de San Andrés. Argentina.

Yeh, Q. J. (1996). The application of data envelopment analysis in conjunction with financial ratios for bank performance evaluation. Journal of the Operational Research Society, 47(8), 980-988.

Yildirim, H. S., \& Philippatos, G. C. (2007). Efficiency of banks: recent evidence from the transition economies of Europe, 1993-2000. The European Journal of Finance, 13(2), 123-143.

Zhao, T., Casu, B., \& Ferrari, A. (2008). Deregulation and productivity growth: A study of the Indian commercial banking industry. International Journal of Business Performance Management, 10(4), 318-343. 


\section{Authors Note}

The authors wish to express their gratitude to the anonymous reviewers for their useful comments on previous versions of this research paper.

Correspondence concerning this article should be addressed to Vincent Charles, CENTRUM Católica Graduate Business School, Pontificia Universidad Católica del Perú, Calle Daniel Alomía Robles 125-129, Los Álamos de Monterrico, Santiago de Surco, Lima 33, Peru. Email: vcharles@ pucp.pe

\section{Biographical Notes}

Vincent Charles is the Director of Research/ Distinguished Research Professor at CENTRUM Católica Graduate Business School. He is an Honorary Professor at MSM, The Netherlands and a PDRF from NUS, Singapore. He is a certified Six-Sigma MBB. He holds Executive Certificates from the HBS, MIT, and RSS. He has 18 years of academic/ consultancy experience and has published over 100 research papers and books. He holds international honours/ awards: the most innovative study to Peru's Think-Tank of the Year; the highly commended award of Emerald/CLADEA and the intellectual contribution award of CENTRUM for three and six consecutive years, respectively.

Claudia Peretto is a Public Accountant with a Master's degree in Applied Statistics from Universidad Nacional de Córdoba (UNC). She is currently pursuing a Doctorate degree and working on her Doctoral thesis (UNC). Claudia is an Associate Professor in Operative Research, Assistant Professor in Financial Mathematics at UNC, and she is member of a research team related to quantitative methods to support decision-making processes.

Tatiana Gherman graduated as an Economist, with a BSc in International Business and Economics from the Academy of Economic Studies of Bucharest, Romania. She then underwent her MBA with a full scholarship at CENTRUM Católica Graduate Business School in Lima, Peru, where she concluded the program as an MBA topper and was awarded the first prize. Her academic achievement has been recognised and awarded by the International Honor Society Beta Gamma Sigma. She is currently a doctoral research student at the School of Business and Economics, Loughborough University, UK, where she is investigating the area of behavioural operational research. 


\section{Appendix A}

\section{CRS Efficiency Indices}

\begin{tabular}{|c|c|c|c|c|c|c|c|c|c|c|c|c|c|c|c|c|c|}
\hline Year & 998 & 999 & 2000 & 2001 & 002 & 2003 & 2004 & 2005 & 2006 & 2007 & 2008 & 2009 & 2010 & 2011 & 2012 & 2013 & 2014 \\
\hline & 464 & & 94 & 5 & 29 & 5993 & 2 & 2 & 5291 & 6579 & 52 & 0.4329 & 0.3906 & & 0.4348 & 0.4444 & 0.4673 \\
\hline Banco de Inversión y Com. Ext. S.A. & $\mathrm{x}$ & $\mathrm{x}$ & $\mathbf{x}$ & $\mathbf{x}$ & $\mathrm{x}$ & $\mathrm{x}$ & $\mathbf{y}$ & $\mathrm{x}$ & $\mathrm{x}$ & $\mathbf{y}$ & $\mathbf{y}$ & $\mathrm{x}$ & 1.0000 & 0000 & .0000 & 00 & .0000 \\
\hline Banco de la Ciudad de Buenos Aires & 0.9434 & 0000 & .9709 & 0.6623 & 0873 & 0000 & 0000 & 1.0000 & 0000 & .0000 & 0.9174 & 1.0000 & 0.7463 & 0.9259 & .9091 & .9259 & 0.8475 \\
\hline Banco de la Nación Argentina & 1.0000 & 2667 & .0000 & 0.8000 & 0.0784 & 0000 & 0.9259 & 1.0000 & 1.0000 & 1.0000 & 0.8547 & 1.0000 & 0.7576 & 1.0000 & & 1.0000 & 1.0000 \\
\hline & 0.8130 & 1912 & 6849 & 0.6329 & 6849 & 6452 & 0.5682 & 0.7299 & 6667 & 8475 & 1.0000 & 0.4902 & 0.3953 & 0.5208 & 0.5181 & 0.5587 & 0.4673 \\
\hline & 0.8929 & & 0.7752 & & 0.0898 & & 0.6024 & & & & & & & & & & 0.6329 \\
\hline ia de Córdoba & 0.5102 & 1376 & 0.6173 & 0.8850 & 1212 & 9009 & 0.8475 & 0.5747 & 5025 & .5650 & 0.5208 & 0.4082 & 0.3401 & 0.4566 & 0.4630 & 0.5051 & 0.5291 \\
\hline & & & 0.6250 & & & & & & .8621 & 4695 & & .7752 & & & & .7299 & 0.8197 \\
\hline & & & & 0.3571 & 0792 & $\mathrm{x}$ & $\mathrm{x}$ & . & $\mathrm{x}$ & $\mathrm{x}$ & . & 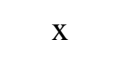 & $\mathrm{x}$ & 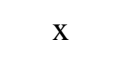 & & 2 & $\mathrm{x}$ \\
\hline & & 0.0672 & 0.3802 & 0.2747 & 0395 & 4219 & 0.2703 & 0.3195 & 3378 & 0.4367 & 0.3676 & 0.3559 & 0.3344 & 0.4785 & 0.4878 & 5291 & 0.5464 \\
\hline & & & & & & 0.6711 & 0.4608 & & & & 0.7092 & & & & 0.5076 & 0.6623 & 0.7353 \\
\hline & 0.8850 & 0.1792 & & & & 0.5952 & & 0.4695 & 0.5025 & 0.8475 & 0.6897 & 0.5682 & 0.3344 & 0.4405 & 0.4386 & 0.5208 & 0.5587 \\
\hline & $\mathrm{x}$ & & 0.7463 & & & 0.6667 & & & & $\mathrm{x}$ & $\mathrm{x}$ & $\mathrm{x}$ & $\mathrm{x}$ & $\mathrm{x}$ & 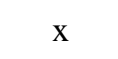 & $\mathrm{x}$ & $\lambda$ \\
\hline & 0.6329 & 0.0996 & 0.7752 & 0.4739 & 0.0623 & 0.6623 & 0.5405 & 0.7353 & 0.6173 & 0.7246 & 0.6623 & 0.4878 & 0.3390 & 0.4505 & 0.4545 & 0.4587 & 0.4673 \\
\hline & 0.7272 & 0.2490 & 0.6645 & 0.6341 & 0.2020 & 0.7391 & 0.6120 & 0.6361 & 0.6556 & 0.7316 & 0.7095 & 0.6103 & 0.5368 & 0.6615 & 0.5905 & 0.6650 & 0.6726 \\
\hline & 0.1801 & 0.2394 & 0.1905 & 0.2281 & 0.2922 & 0.1729 & 0.2215 & 0.2354 & 0.2108 & 0.1973 & 0.2129 & 0.2241 & 0.2628 & 0.2316 & 0.2378 & 0.2055 & 0.2018 \\
\hline $\mathrm{CV}$ & $25 \%$ & $96 \%$ & $29 \%$ & $36 \%$ & $145 \%$ & $23 \%$ & $36 \%$ & $37 \%$ & $32 \%$ & $27 \%$ & $30 \%$ & $37 \%$ & $49 \%$ & $35 \%$ & $40 \%$ & $31 \%$ & $30 \%$ \\
\hline
\end{tabular}




\section{Appendix B}

VRS Efficiency Indices

\begin{tabular}{|c|c|c|c|c|c|c|c|c|c|c|c|c|c|c|c|c|c|}
\hline Year & 998 & 999 & 000 & 2001 & 002 & 003 & 2004 & 005 & 006 & 2007 & 2008 & 9 & 2010 & 2011 & 2 & 2013 & 4 \\
\hline Bar & 6897 & 2370 & 943 & 0.5464 & 2793 & 8696 & 00 & 4587 & 6289 & 8696 & 0.4808 & 0.55 & 4464 & 99 & 5 & 39 & .5076 \\
\hline Com & $\mathrm{x}$ & $\mathrm{x}$ & $\mathrm{x}$ & $\mathrm{x}$ & $\boldsymbol{\lambda}$ & $\mathrm{x}$ & $\mathrm{x}$ & $\Lambda$ & $\mathrm{x}$ & $\mathrm{x}$ & $\boldsymbol{\Lambda}$ & $\mathrm{x}$ & 1.0000 & 1.0000 & 1.0000 & 1.0000 & 1.0000 \\
\hline anco de la Ciudad de Buenos Aires & .9615 & 00 & 0.9 & 0.98 & 0 & 00 & 1.0 & 1.0 & .0000 & 1.0 & 1.0 & 1.0 & 1.0000 & 1.0000 & 00 & 00 & 1.0000 \\
\hline a & 000 & 000 & 000 & 000 & 000 & 000 & 000 & 000 & 000 & 000 & 000 & 00 & 000 & 000 & 00 & .0000 & .0000 \\
\hline co de I a Pamn & 17 & 97 & 7 & 0 . & 00 & 42 & 94 & 13 & 92 & 09 & 00 & 0. & 54 & 48 & 37 & 0 . & .4762 \\
\hline Banc & 0.9009 & 9709 & 8197 & 0.9346 & 0000 & 8772 & 0.6452 & 714 & 5208 & 0.6329 & 0.7194 & 0.5618 & 0.5348 & 195 & 14 & 897 & 0.7634 \\
\hline de Córdoba & 8 & 37 & 29 & 1 & 00 & 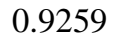 & 29 & 0 . & 02 & 47 & 0. & 0 . & 05 & 30 & 39 & 63 & 0.5952 \\
\hline A. & 7634 & 1828 & 0.8264 & 1.0000 & .0000 & .0000 & 0.7874 & 1.0000 & .0000 & 0.5405 & 1.0000 & 1.0000 & 1.0000 & 1.0000 & 59 & 547 & .9174 \\
\hline $\mathrm{P}_{0}$ & 7 & 1416 & 7 & 0.4 & 20 & $\mathrm{x}$ & $x$ & $\mathrm{x}$ & $\mathrm{x}$ & $\mathrm{x}$ & $\mathrm{x}$ & $\mathrm{x}$ & $x$ & $\mathrm{x}$ & $\mathrm{x}$ & $\mathrm{x}$ & $\mathrm{x}$ \\
\hline Banc & .0000 & .0000 & 1.0000 & 1.0000 & 1040 & 1.0000 & 1.0000 & 1.0000 & 1.0000 & 1.0000 & 1.0000 & 1.0000 & 0.3597 & 0.8475 & 46 & 0.8 & 0.7407 \\
\hline Banc & 1.0000 & 0 & 0.6 & 0.5 & 0 & 1.0 & 1. & 1. & 00 & 00 & 1. & 1. & 67 & 000 & 000 & 1.0000 & 1.0000 \\
\hline Banco 1 & 1.0000 & 15 & 56 & 0.9 & 0.4405 & 79 & 0 & 0 & 48 & 0.9174 & 0.6993 & 0.6667 & 37 & 0.4 & 348 & 0.5747 & 0.5882 \\
\hline Nuevo Banco Bis & $\mathrm{x}$ & 0.6410 & 0.7634 & 0.6250 & 0.6803 & 0.6993 & 0.3788 & 0.3521 & 0.5988 & $\mathrm{x}$ & $X$ & $\mathrm{x}$ & $\mathrm{x}$ & $\mathrm{x}$ & $\mathrm{x}$ & $\mathrm{x}$ & $\mathrm{x}$ \\
\hline $\mathrm{Nu}$ & 0.8696 & 0.1261 & 1.0000 & 0.4926 & 0.2326 & 0.8000 & 0.7353 & 0.8475 & 0.6803 & 0.9174 & 0.6667 & 0.5650 & 0.4098 & 0.4566 & 0.4695 & 0.4630 & 0.4808 \\
\hline $10 \mathrm{Fe}+2+2$ & 0.8679 & 0.4958 & 0.8212 & 0.7922 & 0.6276 & 0.8778 & 0.8027 & 0.7586 & 0.7653 & 0.8503 & 0.8335 & 0.7568 & 0.6239 & 0.7539 & 0.7051 & 0.7521 & 0.7558 \\
\hline Standa & 0.1487 & 0.3700 & 0.1538 & 0.2336 & 0.3839 & 0.1326 & 0.2138 & 0.2492 & 0.2153 & 0.1791 & 0.2008 & 0.2394 & 0.2812 & 0.2447 & 0.2559 & 0.2218 & 0.2204 \\
\hline $\mathrm{CV}$ & $17 \%$ & $75 \%$ & $19 \%$ & $29 \%$ & $61 \%$ & $15 \%$ & $27 \%$ & $33 \%$ & $28 \%$ & $21 \%$ & $24 \%$ & $32 \%$ & $45 \%$ & $32 \%$ & $36 \%$ & $29 \%$ & $29 \%$ \\
\hline
\end{tabular}

